Ophthalmic Res 2015;53:28-29

DOI: $10.1159 / 000365218$

\section{Differentiation of Mesenchymal Stem Cells into Retinal Progenitor Cells}

\author{
Gustavo Sevlever ${ }^{\text {, }}$ Santiago Miriuka ${ }^{a}$, Fernando Pitossib \\ ${ }^{a}$ Institute of Neurological Research, FLENI, and ${ }^{b}$ Fundaciòn \\ Instituto Leloir, Buenos Aires, Argentina
}

Dear Editor,

We read the paper by Moviglia et al. [1] entitled 'In vitro differentiation of adult adipose mesenchymal stem cells into retinal progenitor cells', published in Opthalmic Research, with great interest.

Issues that in our opinion require attention from the authors are listed below.

\section{Identity of Mesenchymal Stem Cells: 'Stemness'}

In a position paper published a few years ago [2], the International Society for Cell Therapy proposed the minimum criteria for defining mesenchymal stem cells (MSCs) as requiring the presence of the following traits: plastic adherence, specific surface antigen expression and multipotent differentiation potential. The cells isolated by Moviglia et al. [1], as described in that paper, only fulfill one of these criteria. The authors do not mention detection of $\mathrm{CD} 105, \mathrm{CD} 73$ or CD90 as positive MSC markers, in the context of negative CD45, CD34, CD14 or CD11b, CD79a or CD19 and HLA class II. Nor does the multipotent differentiation potential appear to have been investigated. Confirmation of the cells described in the paper as MSCs is therefore weak at best.

\section{Induced Differentiation to Retinal Precursor Cells}

The authors developed a system generating retinal precursor cells after a period of $48 / 72 \mathrm{~h}$ of coculture with $\mathrm{T}$ cells, with over $80 \%$ efficiency, and support such amazing results by morphological characterization and immunodetection of several antigens including neu66 (this immunostaining is not shown). This same group reported the use of a similar approach [3] related to neural precursors stating '.. . autoreactive cells may induce the transdifferentiation of MSCs to neural stem cells ...' and later published other papers in 2006 and $2009[4,5]$ on the application of this technique in 2 patients, with no further reports since then. We are unaware of any other publication in the leafy literature on regenerative medicine, describing a phenomenon of this nature induced only by coculture with $\mathrm{T}$ lymphocytes, obtained after such a short time period and with such a high level of efficiency.

\section{KARGER 125}

2014 S. Karger AG, Base

$0030-3747 / 14 / 0531-0028 \$ 39.50 / 0$

E-Mail karger@karger.com

www.karger.com/ore
Characterization of Progenitor Retinal Cells

It is in this context that rigorous identification and characterization of progenitor retinal cells acquires an urgent need. The authors performed several immunodetections: Pax6, TUBB3, bestrophin 2, glial fibrillary acidic protein, RPE65, OPN1 SW, neu66 and rhodopsin. Of this panel, the authors do not show the immunostaining performance of Pax6, RPE65, neu66 or rhodopsin. Nor was any molecular characterization performed, or phagocytic activity analysis by fluorescent latex bead uptake, or calcium imaging as described in several reports dealing with progenitor retinal cell biology $[6,7]$.

The described immunophenotype alone seems insufficient to define a cell lineage in this context. As an example, bestrophin 2 has also been described in colonic goblet cells [8].

There are also several rather intriguing errors in the list of bibliographic references.

In the introduction, reference 1 , a widely quoted paper, does not correspond to the one first listed by the authors, namely Jeganathan VS, Palanisamy M: Treatment viability of stem cells in ophthalmology [Curr Opin Ophthalmol 2010;21:213-217]. We assume that the correct and absent paper is most probably Baker PS, Brown GC: Stem-cell therapy in retinal disease [Curr Opin Ophthalmol 2009;20:175-181], a reference not alluded to at any point in the paper.

The authors refer to a previous paper published by their group in reference No. 5, but again, No. 5 in the list submitted is a publication from a different group. The reference they would seem to be quoting is the one listed as 6 . This mistake occurs twice.

Reference 10, mentioned together with others in the results section, does not refer to retinal precursor cells as quoted in the text.

The authors quote from reference No. 15 as follows: '... According to Moalem et al., this differentiation induction has been attributed to the specific protective action of the tissue-specific autoimmune cells ...' This is not a finding supported by the paper of Moalem et al. [9], which in fact refers to protection given to axons by $T$ cells through a proposed induction of a resting state, in a crush injury model of the optic nerve. The word 'differentiation' is not even mentioned in their paper.

To sum up, the findings of Moviglia et al. [1] fall short of providing evidence for their conclusions, for the following reasons:

MSCs were not characterized as suggested by the International Society Consensus; the revolutionary mechanism proposed by the authors to induce transdifferentiation is widely unknown in peerreviewed published material and their final product, progenitor retinal cells, have not been characterized fully. Nor does the confusing maze generated by referencing published material contribute to clarify these issues.

In addition, the final sentence of this contribution is of concern. The authors state that ${ }^{\prime} . .$. these promising results have prompted us

Gustavo Sevlever, MD, PhD

Neuropathology Department

FLENI (Institute of Neurological Research)

Montañeses 2325, Buenos Aires 1428 (Argentina)

E-Mail gsevlever@fleni.org.ar 
to develop a therapeutic approach similar to the one that was described for chronic spinal cord injury'. By definition, such therapeutic approaches require exhaustive preclinical investigation prior to developing strategies with clinical implications. In addition, to the best of our knowledge, no therapeutic approach involving the use of the technique described has been authorized for use in a clinical trial by local health authorities from the Argentine Ministry of Public Health or the Organ Allocation Regulatory Agency (INCUCAI).

Moreover, 2 unfortunate issues have occurred recently: the publication of a purported in vitro differentiation of mature human cells into neurons [10], which subsequently led to the paper's retraction [11], and the article entitled 'Stimulus-triggered fate conversion of somatic cells into pluripotency' [12], the latter generating harsh controversy $[13,14]$ regarding data legitimacy. These cases deeply stress the meticulous validation that becomes imperative for the field.

Regenerative medicine is a most exciting area of research, one of the most cited in biomedical publications at present. Nevertheless, the distance remains long for promises and hopes raised in this field to translate into applicable clinical practices. Researchers hold great responsibility in moving this field forward and should adhere to strict standards, including preclinical studies with rigorously tested and characterized cell types, as well as full understanding of their specific biology, if successful results are to be achieved in a safe and timely fashion.

\section{References}

1 Moviglia GA, Blasetti N, Zarate JO, Pelayes DE: In vitro differentiation of adult adipose mesenchymal stem cells into retinal progenitor cells. Ophthalmic Res 2012;48(suppl 1):1-5.

-2 Dominici M, Le Blanc K, Mueller I, Slaper-Cortenbach I, Marini F, Krause D, Deans R, Keating A, Prockop DJ, Horwitz E: Minimal criteria for defining multipotent mesenchymal stromal cells. The International Society for Cellular Therapy position statement. Cytotherapy 2006;8: 315-317.

-3 Moviglia GA, Varela G, Gaeta CA, Brizuela JA, Bastos F, Saslavsky J: Autoreactive $\mathrm{T}$ cells induce in vitro $\mathrm{BM}$ mesenchymal stem cell transdifferentiation to neural stem cells. Cytotherapy 2006;8:196-201.
4 Moviglia GA, Fernandez Viña R, Brizuela JA, Saslavsky J, Vrsalovic F, Varela G, Bastos F, Farina P, Etchegaray G, Barbieri M, Martinez G, Picasso F, Schmidt Y, Brizuela P, Gaeta CA, Costanzo H, Moviglia Brandolino MT, Merino S, Pes ME, Veloso MJ, Rugilo C, Tamer I, Shuster GS: Combined protocol of cell therapy for chronic spinal cord injury. Report on the electrical and functional recovery of two patients. Cytotherapy 2006;8:202-209.

5 Moviglia GA, Varela G, Brizuela JA, Moviglia Brandolino MT, Farina P, Etchegaray G, Piccone S, Hirsch J, Martinez G, Marino S, Deffain S, Coria N, Gonzáles A, Sztanko M, Salas-Zamora P, Previgliano I, Aingel V, Farias J, Gaeta CA, Saslavsky J, Blasseti N: Case report on the clinical results of a combined cellular therapy for chronic spinal cord injured patients. Spinal Cord 2009;47:499-503.

-6 Mekala SR, Vauhini V, Nagarajan U, Maddileti S, Gaddipati S, Mariappan I: Derivation, characterization and retinal differentiation of induced pluripotent stem cells. J Biosci 2013;38:123-134.

7 Schmitt S, Aftab U, Jiang C, Redenti S, Klassen H, Miljan E, Sinden J, Young M: Molecular characterization of human retinal progenitor cells. Invest Ophthalmol Vis Sci 2009;50:5901-5908.

$\checkmark 8 \mathrm{Yu}$ K, Lujan R, Marmorstein A, Gabriel S, Hartzell HC: Bestrophin-2 mediates bicarbonate transport by goblet cells in mouse colon. J Clin Invest 2010;120:1722-1735.

-9 Moalem G, Leibowitz-Amit R, Yoles E, Mor F, Cohen IR, Schwartz M: Autoimmune $\mathrm{T}$ cells protect neurons from secondary degeneration after central nervous system axotomy. Nat Med 1999;5:49-55.

10 Qiang L, Fujita R, Yamashita T, Angulo S, Rhinn H, Rhee D, Doege C, Chau L, Aubry L, Vanti WB, Moreno H, Abeliovich A: Directed conversion of Alzheimer's disease patient skin fibroblasts into functional neurons. Cell 2011;146:359-371.

11 Qiang L, Fujita R, Yamashita T, Angulo S, Rhinn H, Rhee D, Doege C, Chau L, Aubry L, Vanti WB, Moreno H, Abeliovich A: Retraction notice to: directed conversion of Alzheimer's disease patient skin fibroblasts into functional neurons. Cell 2014;157:514.

$\checkmark 12$ Obokata H, Wakayama T, Sasai Y, Kojima K, Vacanti MP, Niwa H, Yamato M, Vacanti CA: Stimulus-triggered fate conversion of somatic cells into pluripotency. Nature 2014;505:641-647.

13 http://www.riken.jp/en/pr/topics/2014/20140312_1/ (accessed April 26, 2014).

14 Cyranoski D: Acid-bath stem cell study under investigation. Nature DOI: $10.1038 /$ nature.2014.14738.
Differentiation of Mesenchymal Stem

Cells into Retinal Progenitor Cells
Ophthalmic Res 2015;53:28-29 